\title{
METHOXYFLURANE (PENTHRANE): A LABORATORY AND CLINICAL STUDY*
}

\author{
Gordon M. Wyant, F.F.A.R.C.S., Chung AI Chang $\rtimes$ M.D., D.P.H. (tor.), \\ and Emanuele Rapicavoli, M.D.
}

Methoxyflurane is one in a series of fluorinated compounds which have been studied in recent years to determine their usefulness as anaesthetic agents. Of the many such substances synthetized only few have been sufficiently promising to warrant clinical trials in man; methoxyflurane is one of those.

\section{Chemical and Physical Properties}

Methoxyllurane is 2,2 dichloro-1, 1-difluoro ethyl methyl ether, with the following structural structure:<smiles>FC(Cl)C(F)(F)Cl</smiles>

It is a clear, colourless liquid with a strong sweetish odour. Its boiling point is $104.8^{\circ} \mathrm{C}$. at $760 \mathrm{~mm}$. $\mathrm{Hg}$ pressure which is unusually high for an inhalation anaesthetic agent and it has a specific gravity of 1.4224 at $25^{\circ} \mathrm{C}$. At room temperature methoxyflurane is non-flammable in anaesthetic concentrations. Flash point is $6.3^{-} \mathrm{C}$. and oil/water coefficient of 1 per cent methoxyflurane is 400 . Depending upon the vaporizer, a maximum of 4 per cent methoxyflurane can be vaporized during clinical anaesthesia.

\section{EXPERIMENTAL STUDY}

Following a number of pilot studies the effects of methoxyflurane were studied on five healthy unpremedicated male volunteers using our previously published method of investigating the cardiovascular effects of anaesthetic agents in man. ${ }^{2}$

During a series of pilot studies it had become evident that in these fit unpremedicated individuals induction with methoxyflurane-oxygen alone or with nitrous oxide-oxygen-methoxyflurane was difficult and time consuming, and in rome instances impossible using a standard no. 8 Heidbrink vaporizer with wick. It was further found that if anaesthesia was induced with sodium thiopental and endotracheal intubation done under succinylcholine, it was usually not possible to vaporize sufficient methoxylurane in oxygen to maintain anaesthesia, once the thiopental had worn off. It became evident, therefore, that nitrous oxide-oxygenmethoxyflurane had to be used for some time after induction before the nitrous

${ }^{\circ}$ Generous supplies of methoxylurane (Penthrane ${ }^{(8)}$ ) were made available through the courtesy of Dr. P. Nash of Abbott Laboratories, Montreal, P.Q. who also assisted with a Grantin-aid.

fFrom the Department of Anaesthesia, University of Saskatchewan and Department of Anuesthesia University Hospital, Saskatoon, Saskatchewan. 
oxide could be discontinued. In order to maintain anaesthesia, it was necessary to place three vaporizers, two of them no. 10 Heidbrink type with wicks, in series and having them all in the full-on position (Fig. 1). Attempts at mainte-

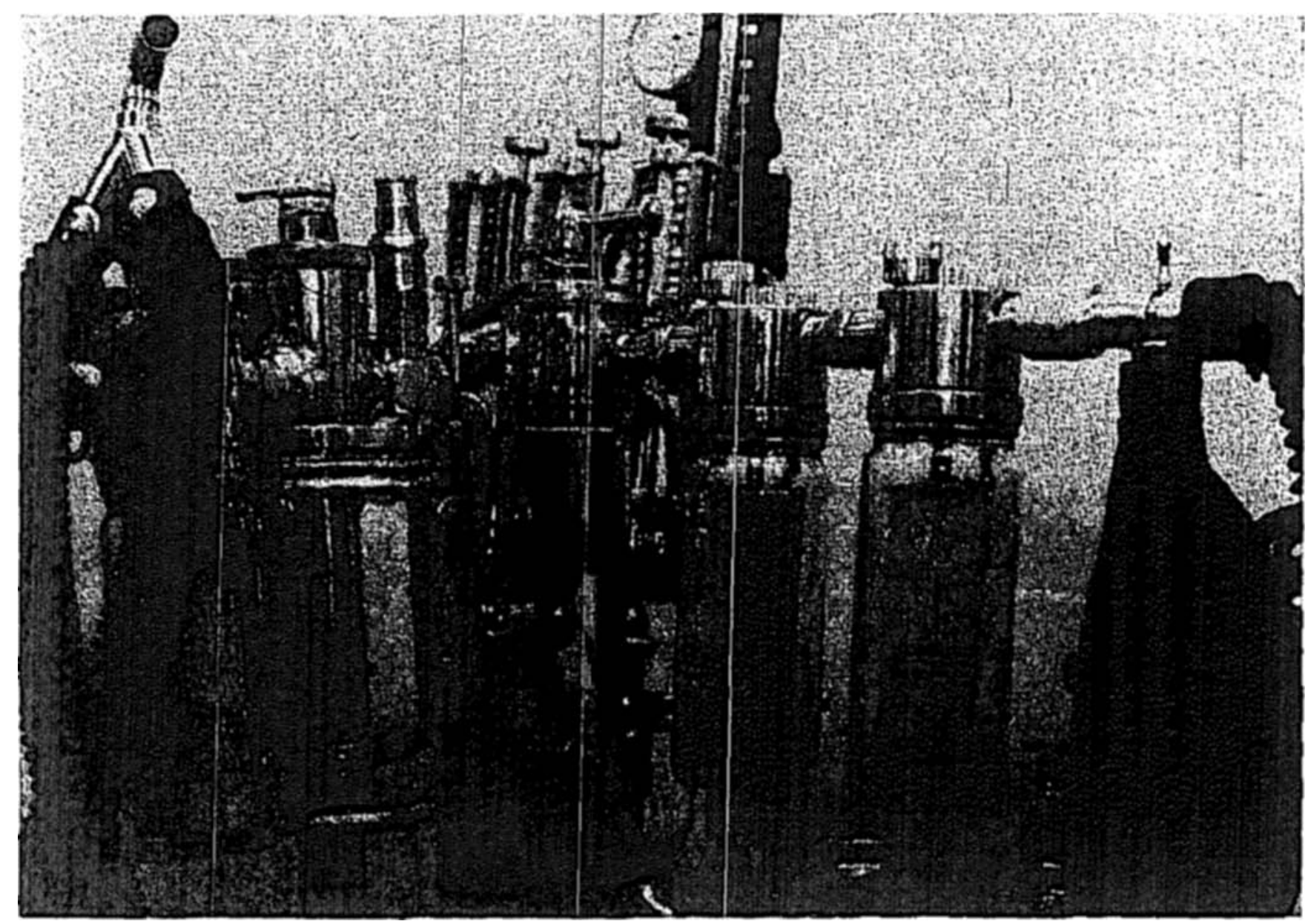

Figune 1. Heidbrink Anaesthetic Machine showing three vaporizers in series for administration of methoxyflurane to volunteers.

nance of anaesthesia in a closed-circle system with the vaporizer on the expiratory side had to be abandoned because the low gas flow made it impossible to vaporize sufficient methoxyflurane to compensate for losses so that the individuals gradually woke up. It must be emphasized, however, that no tests were done with copper-kettle type vaporizers.

Consequently, the method employed in our studies was one of thiopental induction followed by endotracheal intubation under succinylcholine with previous topical anaesthesia to larynx and trachea with 4 per cent lidocaine. Anaesthesia was then maintained with a high flow of nitrous oxide-oxygen and methoxyflurane, the nitrous oxide being discontinued when possible, but usually not before 10 to 15 minutes. After a further 10 minutes of stable anaesthesia with spontaneous respiration, cardiac output was measured and peripheral and pulmonary blood pressures were recorded. Also at that time arterial blood samples were withdrawn from the femoral artery for blood gas determinations. Thereafter, contrgled respiration by means of an Etsten hand ventilator was instituted for 10 minutes, and all measurements repeated. Anaesthesia was then discontinued, the subject was allowed to awaken and all parameters were again measured on recovery. 


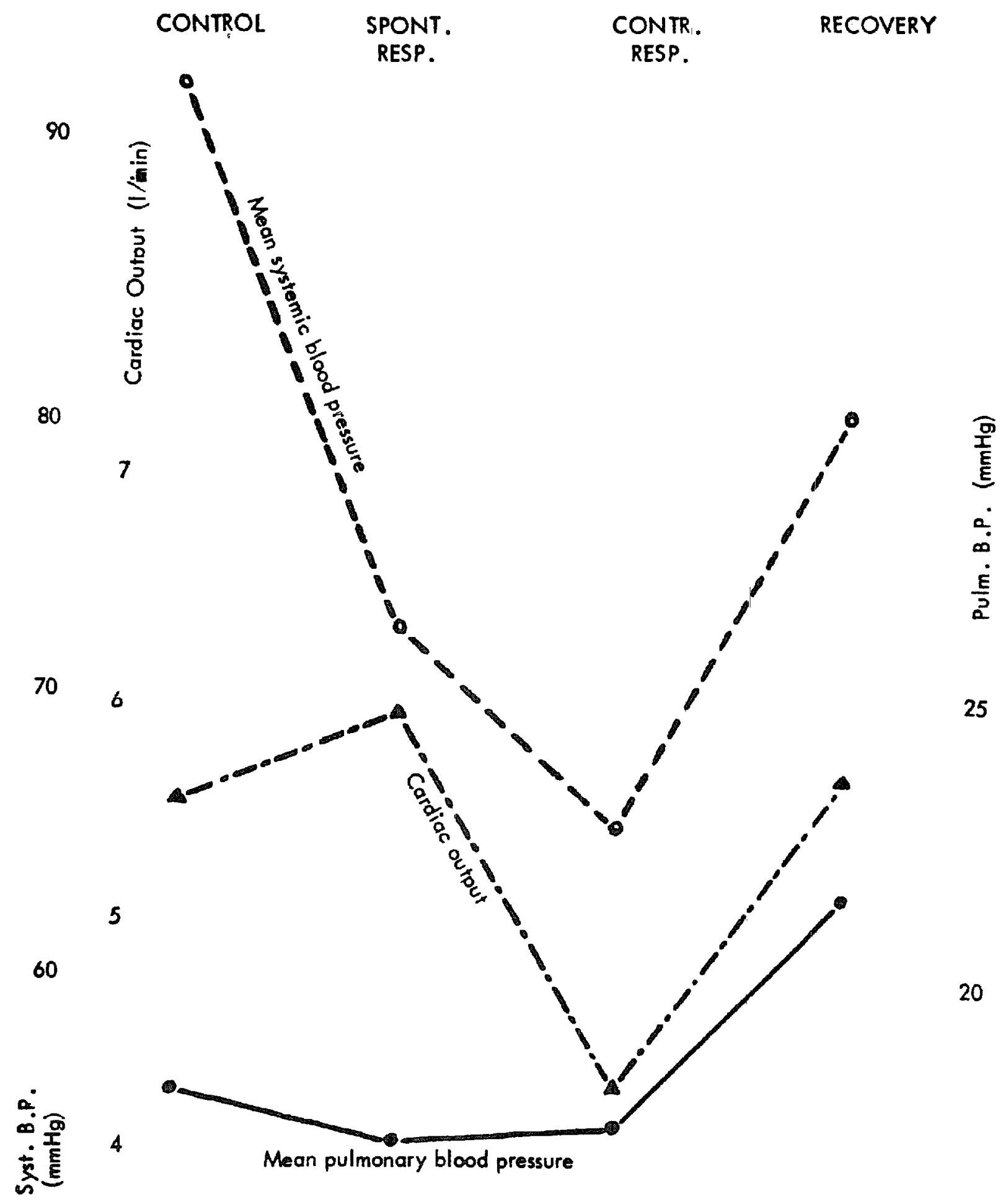

FIGURE 2

Systemic blood pressure (Fig. 2). There was a sharp drop of mean systemic blood pressure from 92 to $72 \mathrm{~mm}$. $\mathrm{Hg}$ during methoxyflurane anaesthesia and spontaneous respiration. A further drop to $65 \mathrm{~mm}$. $\mathrm{Hg}$ occurred with controlled respiration. These changes were statistically valid and occurred in all individuals. On recovery there was a return of mean systemic blood pressure to $80 \mathrm{~mm}$. $\mathrm{Hg}$. Pulse-rate. Mean pulse-rate showed little change throughout the experiments, being $71.3 / \mathrm{min}$. for control, $92 / \mathrm{min}$. for both spontaneous and controlled respirations, and $86.6 \mathrm{~min}$. during recovery. 
Cardiac output (Fig. 2). Little if any change in cardiac output occurred with spontaneous respiration, but there was a drop from 6 to $4.5 \mathrm{~L}$. with controlled respiration and return to pre-anaesthetic levels just prior to awakening. None of these changes were significant.

Stroke volume. This followed closely upon cardiac output being $78.3 \mathrm{ml}$., $65 \mathrm{ml} ., 46.1 \mathrm{ml}$., and $65.7 \mathrm{ml}$. respectively for the four stages of the experiment.

Pulmonary blood pressure (Fig. 2). This did not change significantly during the entire experiment and remained within normal limits throughout.

Total peripheral resistance (Fig. 3). Some slight decrease occurred during spontaneous respiration followed by an increase during controlled respiration which was significant. Resistance returned to control values on recovery.

Total pulmonary resistance (Fig. 3). This showed no change during spontaneous respiration, but there was a rise during controlled respiration with a fall

1500

1000

$$
\begin{array}{ccc}
\text { CONTROL } & \text { SPONT. } & \text { CONTR. } \\
\text { RESP. } & \text { RESP. } &
\end{array}
$$
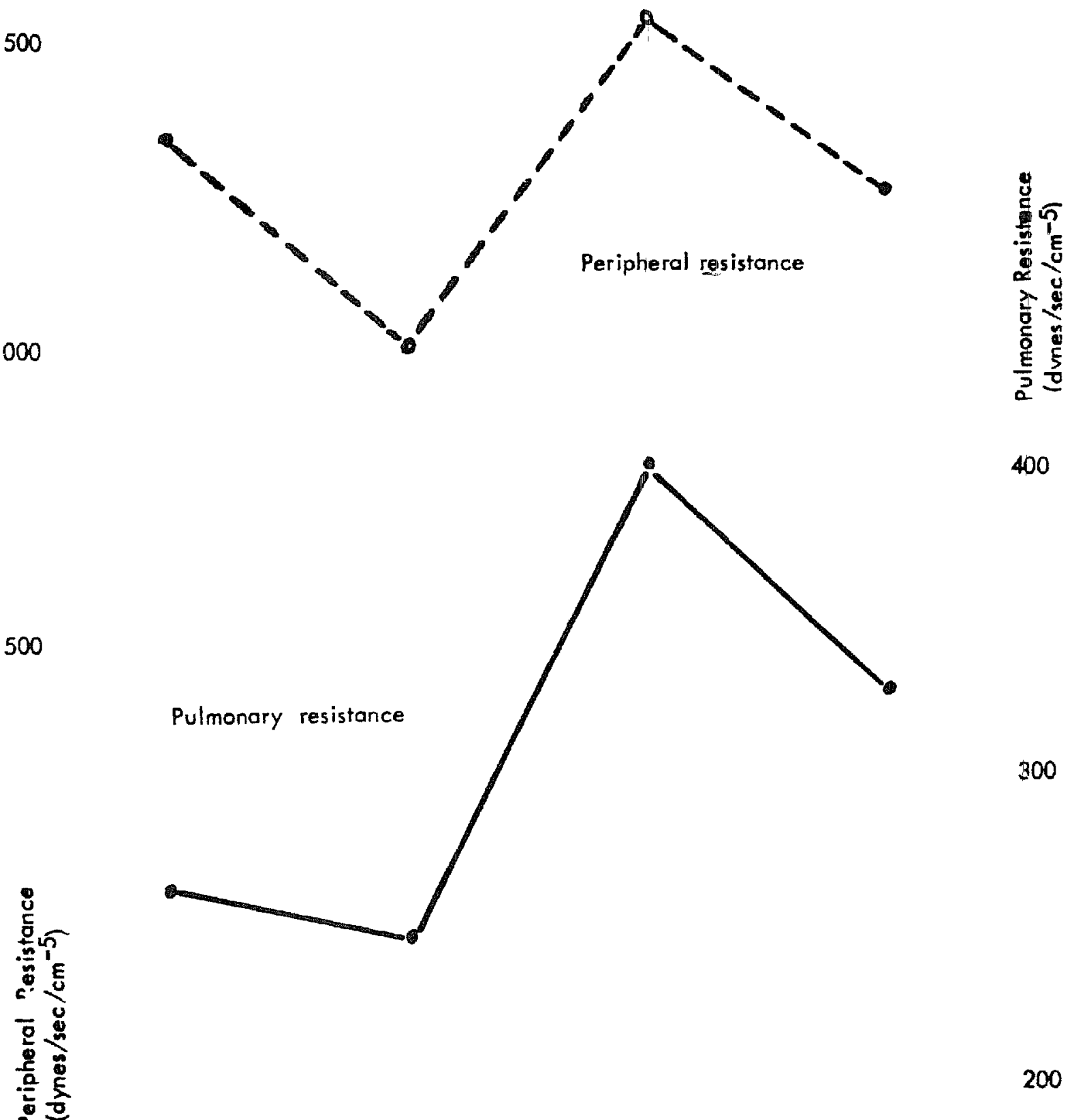

Figure 3 
towards normal on recovery. However, none of these changes were of statistical significance.

Electrocardiogram. No changes were observed in the electrocardiogram in any of the experiments.

Electroencephalogram. This was not specific but was compatible with light anaesthesia.

Blood gases (Fig. 4). A very sharp drop occurred in the $\mathrm{pH}$ on spontaneous respiration with a slight recovery during controlled respiration. Equally the $\mathrm{pCO}_{2}$

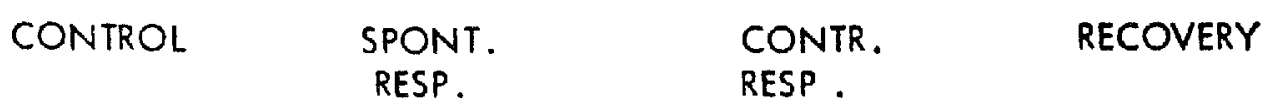

60

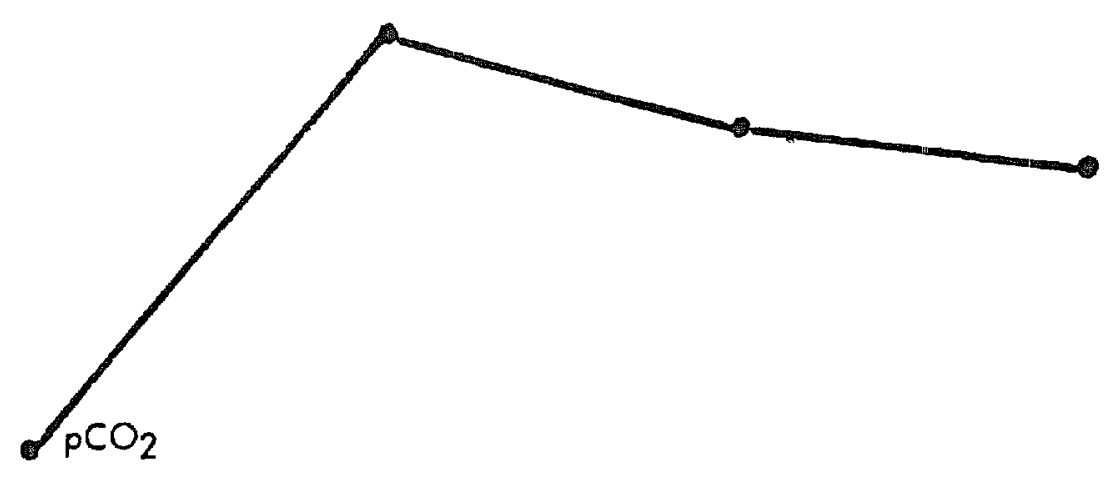

$40 \quad 25$

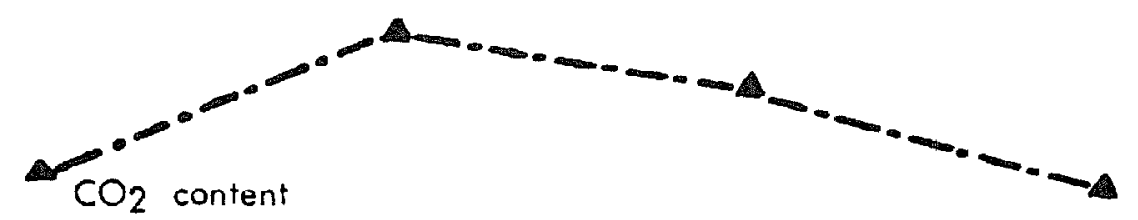

20

20
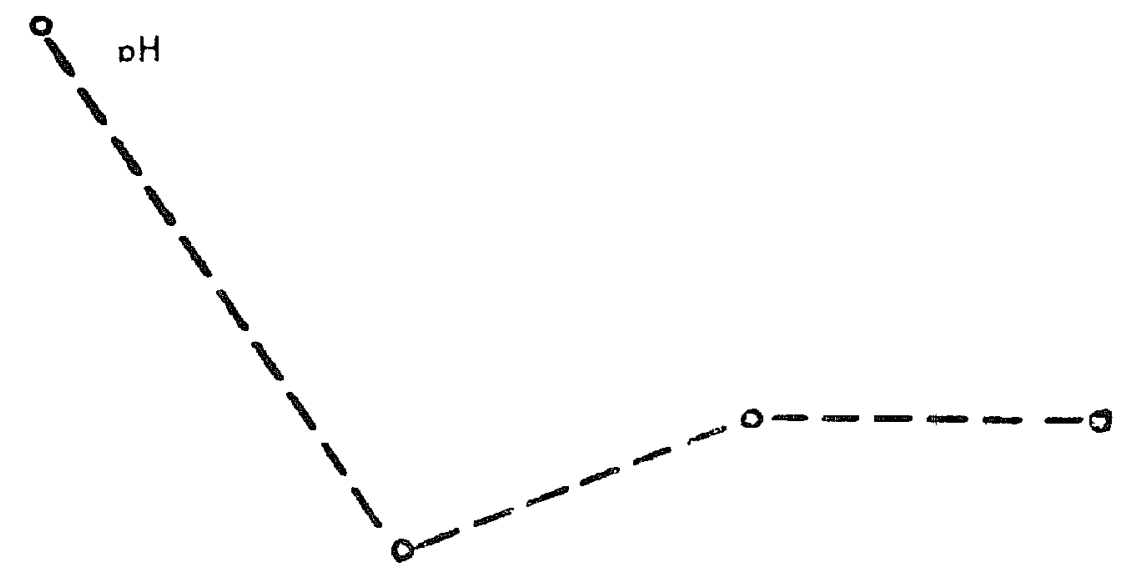

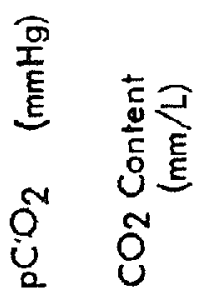


rose sharply on spontaneous respiration but only gradually fell off during controlled respiration and recovery. Changes in $\mathrm{CO}_{2}$ content were insignificant. These findings were in conformity with the clinical observation of powerful respiratory depression by methoxyflurane.

\section{Clinical Study}

Methoxyflurane was administered to 89 patients as a supplement to nitrous oxide anaesthesia. All but seven were gynecological procedures. Nitrous oxideoxygen-methoxyflurane was used both for induction and maintenance 13 times and all but one of these were the earliest cases in this series. For the remaining 76 procedures, thiopental induction preceded maintenance with nitrous oxideoxygen-methoxyflurane. Of these 76 cases, 63 were for major surgical procedures and 10 for minor. Seventy-seven patients were premedicated with morphine and scopolamine, eight with meperidine and scopolamine, one with atropine only, and the remainder had secobarbital and scopolamine. The average time of administration of premedication was 102 minutes pre-induction with a maximum of 340 minutes and a minimum of nine minutes. The average age of the patients was 41 years and 5 months, the youngest being 13 years, the oldest 76 years. Seventy patients received a muscle relaxant, 56 of them dimethyl-tubocurarine. Nine patients were given a single dose of succinylcholine for intubation only, all in cases which did not involve laparotomy. Repeated doses of succinylcholine for prolonged relaxation were given once, and four patients had gallamine for relaxation. In three cases anaesthesia was reinforced by small intravenous doses of meperidine. In the nitrous oxide-oxygen-methoxyflurane induction series, only two patients had dimethyl-tubocurarine for abdominal relaxation and one succinylcholine for intubation. All others were managed without muscle relaxants in order to assess the relaxant properties of methoxyflurane.

Duration of anaesthesia (Table I). The average duration of anaesthesia was 108.1 minutes and the average duration of administration of methoxyflurane was 86.3 minutes. In other words, methoxylurane was on the average discontinued 21.8 minutes before nitrous oxide.

TABLE I

Duration

\begin{tabular}{|c|c|c|c|c|}
\hline & $\begin{array}{l}\text { Number of } \\
\text { cases }\end{array}$ & $\begin{array}{c}\text { Anaesthesia } \\
\text { (min.) }\end{array}$ & $\underset{\substack{\text { (min.) } \\
\text { Methoxyflurane }}}{ }$ & $\begin{array}{l}\text { Methoxyflurane } \\
\text { discontinued } \\
\text { before end of } \\
\text { anaesthesia } \\
\text { (min.) }\end{array}$ \\
\hline $\begin{array}{l}\text { Nitrous oxide-methoxyflurane } \\
\text { (induction and maintenance) }\end{array}$ & 13 & 108.4 & 89.6 & 18.8 \\
\hline $\begin{array}{l}\text { Thiopental nitrous oxide- } \\
\text { methoxyflurane } \\
\text { (major operations) }\end{array}$ & 66 & 119.4 & 946 & 248 \\
\hline $\begin{array}{l}\text { Thiopental nitrous oxide- } \\
\text { methoxyflurane } \\
\text { (minor operations) }\end{array}$ & 10 & 32.5 & $2 \bar{\tau} .2$ & 5.3 \\
\hline TOTAL AND AVERAGE & $8 !$ & 108.1 & 86.3 & 218 \\
\hline
\end{tabular}


Amount of methoxyflurane used (Table II). The average amount of methoxyflurane used was $17 \mathrm{ml}$. per operation or $0.2 \mathrm{ml}$. per min. of methoxyflurane administration. These figures were higher for those cases in which methoxyflurane induction was used and lower with thiopental induction.

TABLE II

AMOUNT

\begin{tabular}{lccc}
\hline & $\begin{array}{c}\text { Number of } \\
\text { cases }\end{array}$ & $\begin{array}{c}\text { Methoxyflurane } \\
\text { (ml.) }\end{array}$ & $\begin{array}{c}\text { Methoxy } \\
\text { flurane/min. } \\
\text { administration }\end{array}$ \\
\hline $\begin{array}{c}\text { Nitrous oxide-methoxyflurane (induction) } \\
\text { Thiopental nitrous oxide-methoxyflurane } \\
\text { (major operations) }\end{array}$ & 13 & 28 & 031 \\
$\begin{array}{c}\text { Thiopental nitrous oxide-methoxyflurane } \\
\text { (minor operations) }\end{array}$ & 66 & 167 & 017 \\
$\quad$ TOTAL AND AVERAGE & $\frac{10}{89}$ & $\overline{17}$ & 0.16 \\
\hline
\end{tabular}

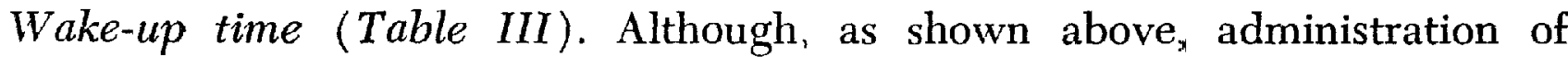
methoxyflurane was on the average discontinued 21.8 minutes before the end of anaesthesia, the average wake-up time after anaesthesia was still 36.6 minutes, or 59.1 minutes after methoxyflurane had been discontinued. Again these figures were higher where nitrous-oxide-oxygen-methoxyflurane was used both for induction and for maintenance of anaesthesia and could be markedly reduced by using thiopental as the induction agent.

TABLE III

WAKE-UP TIME

\begin{tabular}{lccc}
\hline \hline & $\begin{array}{c}\text { Number of } \\
\text { cases }\end{array}$ & $\begin{array}{c}\text { Postoperative } \\
\text { (min.) }\end{array}$ & $\begin{array}{c}\text { Post- } \\
\text { methoxyfurane } \\
\text { (min.) }\end{array}$ \\
\hline $\begin{array}{c}\text { Nitrous oxide-methoxyflurane (induction) } \\
\text { Thiopental nitrous oxide-methoxyflurane } \\
\text { (major operations) }\end{array}$ & 13 & 54.6 & 73.8 \\
$\begin{array}{c}\text { Thiopental nitrous oxide-methoxyflurane } \\
\text { (minor operations) }\end{array}$ & 66 & 351 & 60.9 \\
$\quad$ TOTAL AND AVERAGE & $\overline{89}$ & $\overline{228}$ & $\mathbf{3 6 . 6}$ \\
\hline
\end{tabular}

In order not to prejudice results by early cases in which experience had to be gained with methoxyflurane, cases done in 1960 were analysed separately from those done in 1961. No difference was noted in these and they have therefore been presented together.

Complications. Both operative and postoperative complications were few. Severe hypotension occurred only once in this series and this was easily reversed by reducing the concentration of the drug. Reduced minute volume was a common finding and necessitated assisted or controlled respiration. Postoperatively apnoea occurred three times and on only two occasions did it respond to anticholesterase drugs. Since in these, as in all other cases, muscle relaxants 
had been used sparingly, this condition was no doubt due to the potentiating effect between methoxyflurane and the non-depolarizing muscle relaxants. The third apnoea must have been due to the respiratory depressant effect of methoxyflurane itself and resolved spontaneously after a period on the respirator. Really severe postoperative nausea and emesis occurred only once in this series and in this respect methoxyflurane compared very favourably with other agents.

\section{Discussion}

The experiments on volunteers proved that methoxyflurane caused some hypotension, but in the presence of a reasonably well maintained cardiac output. stroke volume, and total peripheral resistance this was not of very great significance.

Effect of methoxyflurane on the pulmonary circulation was negligible. The absence of electrocardiographic changes was quite striking. In unpremedicated persons it is quite difficult to maintain anaesthesia with methoxyflurane using standard vaporizers with wicks, because of the high boiling point and the difficulty in obtaining adequate concentrations of the drug. Much more striking than the cardiovascular effects was the marked respiratory depression caused by the drug. This was evidenced by changes in $\mathrm{pH}_{8}$ and $\mathrm{pCO}_{2}$ when the subjects were allowed to breathe spontaneously for any length of time. Clinically also there was marked reduction of tidal volume. This effect on the respiration is not too significant as long as it is remembered that at least assisted or, probably better, controlled respiration must be used with methoxyflurane.

The most striking impression gained from the clinical use of methoxyflurane was the apparent unpredictability of wakening time after administration of this agent. Even if administration had been discontinued a good time before the operation ended, the patient often still continued to sleep for quite a long period of time after relatively small amounts of the drug had been exhibited, when in other cases the patient awoke almost immediately after a very much larger dose. These results bear no clear relationship to duration of administration, age, or any similar factors which commonly influence wakening time after anaesthesia. However, recovery time was usually shorter in obese patients, all else being equal. This was exemplified in the following two instances.

The longest wake-up time after discontinuing methoxyflurane was 235 minutes and followed gastrectomy in a 51-year-old man who was $67 \frac{12}{12}$ inches tall and weighed 162 pounds. The duration of methoxyflurane administration was 165 minutes, it having been discontinued 50 minutes before the end of anaesthesia. 'The amount of the drug administered in a semiclosed system with high nitrous oxide-oxygen flows was $30 \mathrm{ml}$. In contrast the patient who had received the largest amount of methoxyllurane, namely $60 \mathrm{ml}$., woke up within 50 minutes of the end of administration of the drug. This was a 36-year-old woman, 62/2 inches tall and obese with a body weight of 153 pounds. She underwent tuboplasty and uterine suspension which involved 190 minutes of anaesthesia with methoxyflurane discontinued 20 minutes before end of anaesthesia.

This curious phenomenon can be explained by the observation of Chenoweth ${ }^{3}$ that methoxyflurane concentration tends to increase in the fatty deposits of dogs even after administration of this drug has been discontinued and the animals 
begin to awaken. Thus the blood level of methoxyflurane falls more rapidly if the agent can escape into abundant fatty deposits while being exhaled at the same time. In lean individuals, fall of blood concentrations is largely dependent upon pulmonary elimination only and awakening is consequently slower. Hence the apparent paradox that in the lean person administration must be tapered off even earlier than in the obese, which is contrary to experience with other anaesthetic agents. While slow awakening is not necessarily a great handicap where good postoperative supervision is available, it could be significant when no postoperative observation area is available.

Methoxyflurane is not easily adaptable to the changing needs for 1 different depths of anaesthesia, as it takes some time to deepen anaesthesia and even longer to reverse undue depth. Thus methoxyflurane lacks a degree of flexibility.

On the positive side of the ledger, on the other hand, is the small incidence of operative and postoperative complications and the fact that the difficulty in volatilizing the drug implies a certain safety factor which must not be easily overlooked.

Induction with nitrous oxide-oxygen-methoxyflurane is a relatively slow process and can hardly ever be accomplished in under five minutes. Induction and also maintenance with methoxyflurane are easier and less of the drug is required if patients are adequately premedicated.

Muscle relaxation with methoxyflurane is quite adequate for lower abdominal operations. However, since this involves the administration of somewhat larger concentrations with further delay in wakening, it is better to use small doses of muscle relaxants and thus decrease the amount of methoxyflurane required. Furthermore, hypotension may be caused by attempting to produce profound muscle relaxation with methoxyflurane.

\section{Summary and Conclusion}

Methoxyflurane is a new fluorinated and chlorinated saturated asymmetrical ether whose outstanding physical properties are an unusually high boiling point and the fact that it is non-flammable in anaesthetic concentrations.

Its greatest usefulness seems to lie in its role as an adjuvant to nitrous oxide anaesthesia. Methoxyflurane is a potent respiratory depressant but has relatively little effect on the cardiovascular system. Profound hypotension will occur with undue depth of anaesthesia but changes in the electrocardiogram have not been observed.

Methoxyflurane lacks a certain degree of flexibility as far as ready changes in depth of anaesthesia are concerned and on occasion recovery from anaesthesia is quite markedly delayed. There is some evidence that the drug concentration increases in the adipose tissue after administration has been discontinued, thus accelerating the lowering of plasma levels in the obese patient and decreasing wakening time. Since it is a rather long-acting agent, administration should be discontinued well before the end of operation and concentrations should be tapered off even earlier.

Methoxyflurane is capable of producing a degree of abdominal muscle relaxation but it is recommended that small doses of muscle relaxants be used in order 
to reduce the amount of methoxyflurane required. The agent enhances the effect of the non-depolarizing muscle relaxants. Although induction of anaesthesia with nitrous oxide-oxygen-methoxyflurane is possible and is not unpleasant, it is slow, implies the use of more methoxyflurane, and is undesirable from the point of view of awakening. It is therefore recommended that anaesthesia be induced with intravenous barbiturates and adequate premedication is desirable.

Administration of a nitrous oxide-oxygen-methoxyflurane sequence was accompanied by few operative and postoperative complications and in that regard the drug compared favourably with other anaesthetic techniques.

\section{RÉSUMÉ}

Nous avons étudié le méthoxyflurane dans des conditions précises chez des volontaires mâles en bonne santé sous prémédication en employant notre méthode, publiée antérieurement, pour l'étude des effets cardiovasculaires des agents anesthésiques chez lhomme. Suivant cette procédure, nous avons soumis 89 malades à l'anesthésie.

Le méthoxyflurane est un nouvel éther asymétrique saturé, fluriné, et chloriné. Ses propriétés physiques étonnantes sont: un point d'ébullition extraordinairement élevé et son inflammabilité en concentrations anesthésiques.

Sa plus grande utilité consiste à servir d'adjuvant au cours de l'anesthésie au protoxyde d'azote. Le méthoxyflurane est un puissant dépresseur de la respiration, mais il ne produit que peu d'effet sur le système cardiovasculaire. Si l'anesthésie est poussée à une profondeur inaccoutumée, il s'ensuivra une hvpotension marquée, sans qu'il soit possible toutefois de dépister des changements électrocardiographiques.

Le mythoxyflurane manque de flexibilité si l'on désire des changements dans la profoundeur de l'anesthésie, et il pourra arriver que le réveil soit plutôt tardif.

Il semblerait que ce médicament s'accumule dans la graisse après que l'administration a cessé, produisant ainsi un abaissement des taux dans le plasma des obèses et hâtant le réveil.

Etant donné que le méthoxyflurane produit des effets prolongés, il faut arrêter son administration longtemps avant la fin de l'opération, et il faut diminuer les concentrations encore plus antérieurement.

Le méthoxyflurane peut produire un certain relâchement des muscles abdominaux, mais il est préférable de donner de petites doses de curarisants dans le but de réduire la quantité de méthoxyflurane requise. Cet agent augmente l'effet des myorésolutifs non dépolarisants.

Bien que l'induction de l'anesthésie avec un mélange de protoxide d'azote, oxygène et méthoxyflurane soit possible et ne présente rien de déplaisant, cette induction est lente, nécessite une plus grande quantité de méthoxyflurane et, si lon songe au réveil, on ne peut pas la conseiller. On conseille plutôt une induction avec des barbituriques par voie endoveineuse, et une bonne prémédication est de mise.

L'administration d'un mélange de protoxide d'azote, oxygène et méthoxyllurane pour maintenir l'anesthésie n'a été suivie que de peu de complications opératoires ou post-opératoires, et sous cet angle-là, le méthoxyflurane se compare avantageusement avec les autres techniques anesthésiques. 


\section{REFERENCES}

1. Penthrane (Methoxyflurane, Abbott Laboratories). Brochure made available to investigators.

2. Wyant, G. M., Donaldson, H. V., \& Merriman, J. E. Observations on Pulmonary Circulation during light Ether Anaesthesia in Man. Canad. Anaesth. Soc. J. 8 (1): $28-42(1961)$.

3. Chenoweth, M. B. Blood and Tissue Distribution of Methoxyflurane, Ether, and Chloroform in the Dog. Quoted from 1. 